\title{
Space and place in the healing of life: towards a theology of affirmation in pastoral care and counselling
}

D J Louw

(University of Stellenbosch)

\section{ABSTRACT}

Space and place in the healing of life: towards a theology of affirmation in pastoral care and counselling

How should healing be viewed and what is the contribution of Chrsitian spirituality to the dimension of pastoral therapy and the healing of life? It is argued that pastoral care should supplement the traditional cura animarum with a cura vitae. In this regard the therapeutice value of place and space is explored. A pastoral model for the making of a pastoral diagnosis is proposed wherein a theology of affirmation plays a pivotal role'.

\section{INTRODUCTION}

Within the realm of pastoral theology it is indeed the question whether pastoral care should be reduced to merely the level of skills and therepeutic techniques, to the level of functionalism and pragmatism, or whether it should probe anew into the realm of ontology. With ontology is meant: the quality of human life in terms of our beings, functions and our human quest for meaning.

The article wants to pose the question whether healing should only be assessed in terms of the absence of illness, in terms of biological functioning, psychological stability and social intactness, or also in terms of spiritual and religious categories.

Some of the guiding questions are: What entails the normative dimension of healing and what is the implication of the interplay between God-images, human identity and the capacity to respond in a mature and appropriate way to the demands of life? What is meant by the spiritual dimension of healing from the perspective of the Christian faith and our theological tradition? What is the contribution of the Christian faith to healing and therapy?

1 Through this article I want to honour and thank Prof C Wethmar for our longstanding relationship of trust and friendship. I also want to honour him for his academic, scientific and theological contribution to the reformed paradigm in Systematic Theology. 


\section{HEALING AND ATTITUDE/DISPOSITION}

L P Uys, a nursing expert, formulates health from a normative approach. Thus, health is regarded as a condition of biotic and psychic well-being, which enables one to act freely in all the normative aspects of reality. This means that the structure and functions of bodily tissues (biotics) and the psychic functions, for example emotions, will, intellect, imagination and memory, remain intact. As such, one is then regarded as healthy when capable of logical rational reasoning (logical), constructive formation of culture (historical), relating to others (social), and respectful treatment of nature (ethical). According to Uys anti-normative behaviour in any of these aspects could lead to illness, while normative behaviour could promote health. Thus, for example, the anti-normative use of alcohol (social aspect) could lead to illness, while the normative behaviour socially, in respect of strong bonds of friendship, could prevent psychological disorders (Uys \& Mulder 1984:9).

In her book on HIV/AIDS care and counselling, A van Dyk (2005:92-94) points out the important role of attitude in the process of behavioural change and healing. In order to change people's mindset, it is indeed necessary to change the cognitive structures that govern specific behaviour. However, to promote health the counsellor should establish a person's attitude towards the specific behaviour that needs to be changed before the change can be expected to occur. In the light of the previous, my argument will be that position and attitude within the realm of space play a fundamental role in a spiritual approach to health and healing.

Healing and health is therefore closely related to how one responds to what happens to and befalls you. How one positions oneself according to norms and values in the light of belief systems, is often more fundamental in healing and therapy than psychoanalyses, psychotherapy and changes in the inner or personal structures of the psyche.

Within the tradition of pastoral care, I want to maintain the position that pastoral care is about cura animarum: care of the human souls. My further hypothesis will be that "soul" is much more a relational and systemic entity within the happenstances of life than a fixed, metaphysical substance merely located in the inner, psychic being. People live in place and space and is therefore extremely sensitive to reactions, responses and attitudes within space 
(atmosphere), and place (location, culture, context). The healing of life (cura vitae) is about the quality of place, space and the positive affirmation of our being functions.

\section{THE ESCHATOLOGICAL DIMENSION OF HEALING}

The contemporary concern with health and healing has become a central cultural value. Magazines project youth and physical health as the epitome of human striving and meaningful endeavour. Maximum bodies, bodily fitness, men's health and women's beauty dictate the understanding of human's health. Health as a core cultural value is creating a new religiosity which $\mathrm{S} J$ Hunt (2003:183) calls "healthism". "This term suggests not only a near cultural obsession with health as a matter of being free of sickness, but has come to denote a positive and proactive attitude to health. This preoccupation is derived from a number of wide but overlapping social developments, namely, instrumental rationalism, consumerism, materialistic lifestyles, and the advance of medical science. Healthism represents a focus on optimum performance and efficiency in all aspects of life" (Hunt 2003:183-184). It becomes clear that one cannot separate health from existing cultural contexts ${ }^{2}$.

Health is often regarded as one's normal and natural state. Illness then would be abnormal and unnatural. A definition of health as a state of not-being-ill, implies that health, as such, is the norm. Thus health denotes the absence of sickness. To see health only against the shadow of illness is one-sided. Health should entail much more than the absence of infirmity.

In pastoral care one should start to speak of "human wholeness"3. The reason for that is that health in a Biblical sense

2 Fuehrer (1960:20): 'Gerade an diesem Masstab: Gesundheit = Arbeitsfähigkeit zeigt sich die zweifache Not unserer Zeit. Wer im Produktionsprozess steht darf nicht ausfallen, sonst fehlt eine Arbeits-"Kraft," ein Rädchen im Getriebe .... Der Mensch wird nach seiner Leistung bewertet, nicht nach seinem Menschsein'. Health then equals functionality within the system of money-making and production. What you do is more important than who you are.

3 In it is not always clear what is meant by "wholeness". The notion of wholeness is very popular in literature on healing but is very vague and slippery. Lamb et al (2001:60-69) discuss the two meanings of wholeness: comprehensiveness and integration. Wholeness also implies coherence and 
points to life and salvation (the verb sozo, to save). In a comprehensive approach to health ${ }^{4}$ the use of the term spiritual healing could be too narrow. One can even speak of "faith healing", "divine healing", "miraculous healing" or "charismatic healing". However, the reference to spiritual healing refers to wholeness and a comprehensive understanding of the concept soul, nephesh, which includes embodied life as experienced within the presence of God, as well as within a cultural system and network of relationships. Due to the predominantly synthetic thinking in the Old Testament, basar, flesh, the bodily function is not something separate from the nephesh. Embodiment and soulfulness are complementary categories.

Healthy people in the Old Testament were people who expressed the quality of fullness and well-being of life as represented by the notion of shalom, peace. It refers to complete fulfilment and is connected to moral activity, spiritual achievement, righteousness (sedeq), faithful fulfilment of the covenant and the torah (holiness), obedience to God and the law, blessing, fertility and longevity (see also Wilkinson, 1998:11-16). These concepts, within a comprehensive understanding of health as wholeness and well-being, refer to a positive state of complete fulfilment and a sense of destiny as it emanates from God and his will for a humane life in dignity and righteousness. Health includes right relationships. This comprehensive understanding dovetails with the New Testament's understanding of health and healing. Several concepts are relevant in this regard.

Wilkinson (1998:22-29) discusses the use of the concept hugies, which means having the quality of soundness from a proper balance of the whole being. "The significant point is that both shalom and hugies coincide in expressing the idea of soundness or wholeness of a person's being which is the essence of health" (Wilkinson 1998:22). In this regard eirene describes a state of peace or tranquillity as opposed to war or disturbance. Zoe refers to health

intactness, continuity and adequacy. Self-knowledge and "loving knowledge" also play a role.

$4 \quad$ For a holistic health approach, see Collins et al (2003; 1-7). Important is the fact that modern psychiatry came to the realisation that the spiritual aspect is just as important a component of the total person as are the mind and the body. 
as a constructive way of living, the quality of life, while bios and psuche generally refer to our common human life lived under the conditions of time and sense, which begins with birth and ends with death. When transferred to God, life points to eternal life and trust in the faithfulness of God. Soteria indicates a condition of redemption as the outcome of justification, namely being saved and sound, and deliverance (freedom from evil and sin).

From a theological point of view one can conclude that as a comprehensive category, health refers to a state of being to be described as shalom, peace (Long 2000:14). According to Long, in shalom, or health, our relationships to God, one another, and the environment are at peace. He concludes: shalom is experienced in a right relationship to God; it is experienced communally; it is experienced in a very special way within the family system and should be expanded to the whole of creation. Shalom therefore denotes: fullness of life.

According to Pilch (2000:4-15) the healing stories in the New Testament and the notion of shalom should be interpreted in cultural context. When one compares the notion of healing in an ancient narrative with the notion of healing in for example a Westernised and Americanised global context, different perspectives surfaces. When applied to the American context healing is more about doing, individual need-satisfaction, future success and achievements, the attempt to master and control and the pursuit of happiness (what is good)(with the emphasis on the doing functions).

Within the New Testament, being is more primary than doing. Collateral relationships constitute the primary value orientation. Group goals are therefore preferable to individual goals. Both the past (tradition) and the focus on everyday life in the present are important. Life should be lived not managed. Part of the reality of everyday life is the interplay between good and evil.

\section{HEALING AND GOD-IMAGES}

Healing and health can never be separated from the realities of suffering, disfigurent and human failure and disabilities. Eiesland (1994:70) points out that the persistent thread within the Christian tradition has been that, as in the case of suffering, disability denotes an unusual relationship with God and that the person with disabilities is either divinely blessed or damned: the defiled evildoer or the spiritual superhero. In this regard a unilateral and biased 
exegesis functioned in terms of several Biblical texts, for example Leviticus 21:17-23 that prohibits people with disabilities and physical handicaps to enter the most holy place in the temple. The sin-disability paradigm also functions in John 9:1-3. It leads to the theme that physical disability is a travesty of the divine image and an inherent desecration of all things holy.

Another theological paradigm that added to the marginalisation of suffering people is what can be called "virtuous suffering" (Eiesland 1994:72). The account of the apostle Paul's "thorn in the flesh" as sign of divine grace (2 Cor. 12:7-10) has been influential in supporting what Eiesland calls a Christian theology of virtuous suffering. Righteous submission to divine testing is upheld as a praiseworthy disposition for Christian disciples. Impairments became signs of divine election by which the righteous were purified and perfected through painful trials. Disability was represented as a temporary affliction that must be endured to gain heavenly rewards.

Eiesland (1994:73) argues that virtuous suffering encouraged our passivity and resignation, and has institutionalised depression and helplessness as an appropriate response to "divine testing"; "... the theology of virtuous suffering has encouraged persons with disabilities to acquiesce to social barriers as a sign of obedience to God and to internalise second-class status inside and outside the church".

The discreditation of suffering, disfigurement and disability can inter alia be linked to a remote God-image which tries to separate God from human suffering and promotes an apathetic God. It is therefore my contention that in pastoral hermeneutics we need to introduce the notion of a suffering disfigured and handicapped God. In this regard we need to deal with the vulnerability of a crucified God (theologia crucis) (see Moltmann 1972). Crucifixion, suffering, guilt and sin cannot be ignored. They are indeed realities to be dealt with in spiritual healing. Due to God's identification with our suffering at the cross, the cross reveals the weakness and vulnerability of God. The cross is about stigma, impairment, disfigurement and disability. In the ugliness of the disfigured and suffering messiah (see Isa 53:2-5) we discover a different relationship between illness, disability and our understanding of 
$\mathrm{God}^{5}$. Paul argues for the weakness of God in terms of a theology of the cross (1 Cor 1:25). The cross is a theological reflection and a fundamental critique, even a protest and lament, on woundedness, weakness, disfigurement, ailment, vulnerability, marginalisation and stigmatisation.

The notion of a disfigured and disabled God in pastoral care and counselling introduces empathy and sympathy, namely pathetic identification. Together, people with disabilities and the able-bodied, must be reconciled with the disabled God through Jesus Christ's broken body in Eucharistic repentance and celebration" (Eiesland 1994:25).

But theology entails more than cross and suffering. Theology is also about the establishment, maintenance, transformation and transfiguration of life and hope (see Moltmann $1966^{5}$ ). The notion of a disabled $\operatorname{God}^{6}$ must be supplemented by the notion a transfigured, powerful, abled $\mathrm{God}^{7}$. The key concept for a theological understanding of God's ability is the notion of trust and the faithfulness of God. All the fulfilled promises of God are displayed in and proofed by the resurrection of Christ (theologia resurrectionis). The resurrection of Christ reveals God's power as faithfulness within the value of physicality and life. It is embodied in a transfigured corporality wherein the stigma of suffering becomes a symbol of solidarity and meaning. Through a theology of the resurrection, the resurrected Christ in presenting impaired hands and feet alters according to Eiesland (1994:101) the taboo of physical avoidance of disability and the degradation of the human body. Life and "soul" is indeed about physicality and embodiment as well.

5 See in this regard the reframing of the notion of power (omnipotence of God) and the translation of el shaddaj with pantokrator, Louw (2000:45-73).

6 "I saw God in a sip-puff wheelchair, that is, the chair used mostly by quadriplegies enabling them to maneuver by blowing and sucking on a straw like device. Not an omnipotent, self-sufficient God, but neither a pitiable, suffering servant. In this moment, I beheld God as a survivor, unpitying and forthright" (Eiesland 1994:89).

7 "Jesus Christ the disabled God, is not about a romanticized notion of "overcomer" God. Instead here is God as survivor. See Eiesland (1994:102). 
In this regard one can indeed argue for a "physical God" in terms of a theology of life, redefined by a theology of resurrection ${ }^{8}$. It is the contention of Eiesland that the significance of the disabled God is not primarily maleness or gender but rather physicality. Resurrection does not romanticise stigmatisation. The resurrection is a cruel revelation and attack on what stigmatisation has done to the human dignity of people. The resurrected Christ is now the stigmatised Jew, person of colour and raped woman. He is the representative of the poor and hungry - those who struggle to maintain the integrity and dignity of their bodies in the face of physical suffering and the physical mutilation of injustice and rituals of bodily degradation.

The disfigurement of the resurrected Christ does not support a theology of sin-disability or virtuous suffering, but a theology of life, embodied within the realities of disfigurement, impairment and disability. Disability does not contradict the human-divine integrity. It does not romanticise about impairment as a virtue. On the one hand it unmasks the pain and injustice due to social marginalisation. At the same time it becomes a new theological model of wholeness and a symbol of empathetic and pathetic solidarity. It becomes a symbol and metaphor for life within disfigurement. It describes ability for life within the disabilities of life. It creates a liberatory realism that accepts barriers but immediately transforms them into new abilities.

The cry of the lament becomes the outcry and articulation of hope. "Hope is the recollection and projection that even our nonconventional bodies, which often dissatisfy and fail us, are worth the living" (Eiesland 1994:103). Even the traumas in life are worth living.

In order to conclude one can say that healing in pastoral care should represent and display a theological interpretation of healing. In this regard the following theological perspectives are relevant:

8 "In the resurrected Jesus Christ, they saw not the suffering servant for whom the last and most important word was tragedy and sin, but the disabled God who embodied both impaired hands and feet and pierced side and the imago Dei. ..... Our body participates in the imago Dei, not in spite of our impairments and contingencies, but through them". 
- Spiritual healing refers to a new state of being (the eschatological perspective): healing represents the fact that "...if anyone is in Christ, he is a new creation" (2 Cor. 5:17). This is a shift from sin into the eschatological realm of redemption and salvation.

- $\quad$ Spiritual healing represents a new state of mind: peace. Shalom describes a contentness with God and life." For he himself is our peace" (Eph 2:14).

- $\quad$ Spiritual healing is about a new attitude and way/mode of doing and living." Live by the Spirit...but the fruit of the Spirit is love, joy, peace, patience, kindness, goodness, faithfulness, gentleness, and self-control" (Gal 5:16, 22-23).

- Spiritual healing indicates wholeness: purposefulness and direction. "For in this hope we were saved" (Rm 8:24).

- Spiritual healing in pastoral care can directly be linked to the appropriateness or inappropriateness of people's God-images. Hence the notion of a suffering and disabled God.

\section{SPACE AND PLACE IN HEALING}

The very surprising fact is that already the Greeks discovered the importance of space and place for our being human. The ancient Greek term chōra, means space or place'. Chōrēo is a verbal derivative of chōros or chöra indicating an open space or land. As an intransitive it means to give room. In an extended and metaphorical sense it can refer to intellectual and spiritual capacities to understand. In this sense space functions as a container of meaning. In the gospel of Matthew (Mt 13:11, $16 \mathrm{ff}, 19,23$ ) it stresses the grasping of the teaching of the parables. Chöreo even "appears to go beyond understanding and points to the capacity to receive and to act upon the teaching" (Schmidt 1975:742). Chōra then becomes an indication of how humans fill space with values, perceptions, and associations in order to create a dynamic relational environment and systemic network of interaction where language, symbol and metaphor shape the meaning and discourses of our life.

9 See for this interpretation, the discussion of Økland (2004:154) on the meaning of chōra and the current debate in French philosophy, for example Derrida. 
The French philosopher, Derrida, calls space a hermeneutic dynamics of interacting discourses (see Økland 2004:154). In the Platonic understanding, chōra is a nourishing and maternal receptacle, and is related to topos, a particular, definable place of human encounter. Topos can also be connected to what can be called "a theology of omnipresence which goes hand in hand with the sublimation of cultic observance" (Haacker 1978:461). As one reads topos together with theological language such as election (ekklegomai, eklektos) place becomes the cultic location of a covenantal encounter between God and his people (Coenen 1975:538).

For the debate on healing in pastoral care chōra shifsts the debate from performance and production, to care and nurturing, to support, surround, protect, incubate and to give birth to life. The feminine and mothering dimension strengthens the notion of the fostering of life; chora is the condition for the genesis of things and being ${ }^{10}$.

One of the main factors that determine space is power. Many life problems are not so much an issue of personality and personality traits or personal characteristics, but reactions and human responses to the power play going on within the systemic space and networking of relationships. Power relationships play a paramount role in the formation of human identity. Thus the importance of the following remark by Castells (2004:7): "the social construction of identity always takes place in a context marked by power relationships...".

In his book Simulcra and Simulation, Baudrillard (1994:3) refers to the space of simulation. "To simulate is to feign to have

10 "Chöra then, is the space in which place is made possible, the chasm for the passage of spaceless Forms into a spatialized reality, a dimensionless tunnel opening itself to spatialization, obliterating itself to make others possible and actual. It is the space that engenders without possessing, that nurtures without requirements of its own, that receives without giving, and that gives without receiving, a space that evades all characterizations including the disconcerting logic of identity, of hierarchy, of being, the regulation of order. It is no wonder that chora resembles the characteristics the Greeks, and all those who follow them, have long attributed to femininity, or rather, have expelled from their own masculine self-representations and accounts of being and knowing (and have thus de facto attributed to the feminine)". See Grosz (1995:116). 
what one doesn't have." Simulation corresponds according to Baudrillard to a short circuit of reality and to its duplication through signs. In this regard the cinema projects a space of "hyper-reality", the cinematographic (or televised) hyperreal.

By way of summarising the importance of space for the understanding of the healing of life, the following bipolar dynamics and constituents of space can be identified.

- Perceptions and the interplay with contextual and local life experiences.

- Different modes of being and the social and cultural structures of life.

- The interplay between time and human vulnerability (the frailty of life).

- $\quad$ Corporeality (presence as embodied space) and sexuality (the principle of erotic desire/libido).

- Ensoulment (significance) and processes of transcending (spirituality).

- $\quad$ Shape \& form (physico-mathematical, topological properties) and relativity (space is relative to the objects within it) (Grosz 1995:97).

- The interplay between space as atmosphere and place as location, territory, possession, occupation and belongingness (see different actions such as penetration, colonisation and domination).

- $\quad$ Subjectivity (unique identity) and processes of networking (interrelatedness).

\section{TOWARDS A THEOLOGY OF SPACE AND PLACE: AFFIRMATION THEOLOGY}

It is indeed not easy to link theology and Christian spirituality to the notion of space and place. It will be argued in this book that with a theology of space is meant the event of the incarnation: God's enfleshment and embodied presence within a human body in and through Christ. The incarnation is the event of the recreation. It constitutes the space of eschatology within the hopeful dynamics of the already and the not yet. 
With a theology of place, as the continuation of an incarnational space, is meant the event of the inhabitation: the indwelling presence of God through the Pneuma in our human bodies (spiritual corporeality).

Both a theology of space and place is about a theology of affirmation, i.e. the constitution of human identity in terms of ontology of salvation (the corporate reality of our new being in Christ and our transformed status as children of God.

There are indeed different options for a theological approach to health and healing.

- The one option is a theology of schematisation. This is an attempt to schematise theology in terms of dogmatic categories in order to get access to an understanding of the very being (substance and essence) of God. The danger in this kind of theology is that it tends to become very rationalistic and often ends up with a very positivistic stance on the relationship between God and life. In such a schematic approach, healing was in the Protestant tradition often reduced to the confession of sins and the notion of justification.

- Another option is liberation theology. During times of oppression liberation theology is an attempt to free human beings from oppressive systems that violates basic human rights. It focuses on the ideology behind social systems in order to free human beings from destructive institutions and patterns of thinking. Liberation theology flourishes during times of revolutionary actions with its main goal and target to transform society. Healing is more or less equivalent to freedom. The problem with liberation theology is that it is a reaction to a very specific social evil, defect or injustice. When the evil is removed the question of a new commitment arises: when one is freed from, one should be freed for, for what?

- A theology of reconstruction is geared toward the restructuring of social structures, which determines the wellbeing of people. This approach is most appropriate when one is called to deal with contextual issues such as poverty. A theology of reconstruction deals inter alia with the redistribution of wealth and issues of inequality. Social healing and reconstruction go hand in hand. The pastoral caregiver is becoming more and more a social worker and operates like a 
social engineer within community development. The problem still prevails: but what about the identity of human beings even under the most severe conditions?

- The aim of a theology of affirmation is to deal with ontological issues, which affect the status and identity of human beings. Within a Christian spiritual approach to life events, a theology of affirmation describes the status of our being human in terms of eschatology. Eschatology is then understood as an ontological category that defines our being human in terms of the events of the cross and the resurrection. Eschatology is about the essence of things, its implication for the end of things and the qualification of time and history, and not in the first place about the end of things and the eventual outcome of history in terms of apocalyptic projections.

Affirmation theology describes signification and ascribes human dignity and subject particularity. It emanates from the ontological Yes in Christ to our being human (as demonstrated through baptism and celebrated in the Eucharist) and is demonstrated in new patterns of pneumatic living (pneumatology and inhabitational theology). The presupposition behind this option for a theology of affirmation is that it can help theology and the church to move in different public discourses beyond the "isms" of our time, for example, to move in the gay debate beyond "gayism". Hopefully it can contribute to the gender debate and help the church to move beyond feminism and patriarchalism ${ }^{11}$. Furthermore, it is my presumption that a theology of affirmation can contribute in the HIV debate to processes of destigmatisation. It can even open up a new and more constructive understanding of the human body and the place of human sexuality in a theological anthropology.

In this regard a theology of affirmation links with recent developments in psychology. The emphasis on positive psychology and its variant fortology, is a movement away from pathology to constructive enforcement and encouragement.

Strümpfer (2006:11-36) points out the importance of fortigenesis in adult life. Fortigenesis (fortis=strong) refers to the strength perspective, which relates human wellness to the positive

11 On patriarchalism and the end of patriarchalism, see Castells (2004:192302). 
components in human behaviour. This approach concentrates on these components in human wellness that create strength, courage and a positive approach to life demands. The background to a "science of strength" is the meaning dimension of life. Interpersonal flourishing and subjective well-being are closely related to one another. Research applications in the field of positive organisational behaviour are developing as part of the paradigm of fortology. Both psychofortology and positive psychology support the development of human strength and its role in motivation and constructive performance. In theological language, fortology and a strengths perspective are the equivalent of what, in the language of existential theology (Paul Tillich), is meant by the courage to be.

The emphasis on strength is to move away from the paradigm of pathogenic thinking and to link health to a sense of coherence, personality hardness, inner potency, stamina or learned resourcefulness (Strümpher 1995:83).

Within the paradigm of a theology of affirmation, "fortigenesis" points more in the direction of existential and ontological categories than mere inner emotional strength and positive behavioural attitudes. A theology of affirmation refers to an ontic state of being, namely, to have your very qualities of being affirmed by eschatology. To be a new being in Christ means to be strengthened by the charisma (fruit) of the Spirit in order to live life in courage and by means of a vivid hope. With spiritual fortigenesis and fortology is meant the kind of spiritual strength and courage that emanates from our new being in Christ. The equivalent in Scripture for fotigenesis is parrhēsia, namely a courage that is not a human quality but a quality that comes from God (I Th. 2:2) and Christ (Phlm. 8). Parrhesia is a pneumatic function as part of the fruit of the Spirit.

\section{A PASTORAL MODEL FOR THE HEALING DYNAMICS OF SPACE IN CAREGIVING: POSITIONING AND THE CREATION OF ATMOSPHERE}

The following model is designed as the outcome of my argument that a theology of affirmation and the concepts of space, place and atmosphere can contribute to a holistic and comprehensive understanding of healing. It is an attempt to put a model for cura vitae over into a graphic design and portrayal. This model can be 
applied in the assessment of the quality of people's attitudes towards life within the process of the making of a pastoral diagnosis.

Atmosphere describes the "climate" as created by the mode in which a person positions him/herself within the space of human encounter.

For the healing of attitude and position two things should take place:

(a) The one is an empathetic valuation, a constructive and positive as well as realistic feedback, in terms of the identity of the human person. The person should be exposed to the experience of being affirmed. In order to put this dynamics into therapeutic language and to describe (a visible portrayal) what is meant by the "atmospheric healing of space", I will make use of the bipolarities of disengagement and embracement. Both distance and nearness are necessary for healing. Between the two there is the option of a neutral stance. These polarities are valid for both the position of the caregiver and the patient within a spiral model.

- Disengagement gives space for unique impute and subject energy. Disengagement creates space for critical self-reflection and self-confrontation.

- Embracement gives space for creating the atmosphere of intimacy: unconditional love and regard. Embracement is an act of human affirmation.

(b) The second is: change and transformation that is directed towards meaning/significance and growth. Within a graphic portrayal the bipolarities of growth are: being with and goal-directed action (meaning giving actions) (significant performance). The atmosphere of being with creates a space of linger and a sense of being at home (guarantee) (geborgenheid). The atmosphere of goaldirected action creates the space of change and hope: something can be done or changed. Within in these two bipolarities a neutral stance is indeed possible. In this regard the being qualities play a fundamental role. Affirmation is to a certain extent a prerequisite for transformation and change.

A third position is indeed possible: a neutral stance. This position describes and indicates either an attitude of contentment (peace) or an attitude of ignorance/avoidance. 
Four possible positions (see the four quadrants) of space are indicated: $A=$ describes a space/position of grace, namely different options that can be explored depending on the maturity of the person and level of responsibility. Options create a sense of anticipation of something different and new and instil a mode of existential hope. $\mathrm{B}=$ describes a space/position of care, help, support and comfort. Within this space a sense of security is created. $\mathrm{C}=$ describes a space/position of confusion due to an experience of rejection. $\mathrm{D}=$ describes a space/position of dislocation due to detachment. Dislocation and detachment lead easily to indifference. D often results in an atmosphere and space of isolation (a possible loss of a sense of belongingness) and can communicate a very artificial atmosphere with the message of falsehood.

The red zones indicate the possible danger zones of space. $\mathrm{E}=$ describes the force of coercion that can easily lead to compulsion and pressure: a stressful atmosphere (performance anxiety, burn out, compassion fatigue). $\mathrm{F}=$ describes enmeshment and therefore an atmosphere of entanglement. $\mathrm{G}=$ describes an atmosphere of stagnation with no possibility of change. $\mathrm{H}=$ describes an atmosphere of repulsion and aversion.

A and B represent the warm side of space (attraction), while C and $\mathrm{D}$ represent the cold side of space (push away). As already said, right in the middle is the possibility of neutrality that can indicate contentment if the direction is towards the warm side $\mathrm{A}$ and $\mathrm{B}$ and ignorance when the direction is towards the cold side $\mathrm{C}$ and $\mathrm{D}$.

The dynamics of space is important for caregiving because it can help the caregiver to assess his/her own attitude within a situation. If the patient/person feels isolated the shift of position should be to the opposite quadrant $\mathrm{C}$, and when there is confusion the shift should be towards A. D is the shadow side of $A$ and $C$ is the shadow side of B. All of the spaces are always existent and present. The diagram should therefore not be interpreted as either/or, but as and/and.

It is sometimes necessary to move to the opposite quadrant but at the same time sidewards to the adjacent quadrant. The portrayal of the dynamics of space should be used as a hermeneutical tool, namely to interpret what is going on within a spiral model and the pastoral space of encounter and communication. It does not explain in terms of cause and effect (an explanatory model). It only points 
out the possible atmospheric environments created by attitudes and how attitudes influence human responses.

It is important to note that the growth axis has got two directions for healing: meaning-giving performance (action and decision-making) as well as patience (wait until). Patience is linked to a sense of silence and solitude. Sometimes it is necessary to work into the direction of meaning-giving actions, goal setting and a structured programme; sometimes it is necessary to wait 'until'. A position of wait implies the entering of the space of silence, which is necessary for spiritual reflection. In this regard silence is a very constructive and positive space to move into.

The space of silence is linked to the healing space of solitude. This 'until' and patience indicates that for many issues, problems and ailments in life there are no solutions. They should be acknowledged, accepted and lived in a constructive and integrated way. For example, it is sometimes necessary to say: it is my cancer, before one can embark on a journey of integrative healing. In order to accept and to change one's attitude, it is of paramount importance to be affirmed in one's being quality. Who you are/being determines the quality of responses. In this respect solitude creates the opportunity to connect to one's spiritual sources for faith, commitment and authenticity (unique identity).

The valuation axis has got the one direction of attraction (pull) when the atmosphere of the encounter is positive and constructive. When it is negative and destructive, the direction is towards an experience of being pushed away (resistance). When the latter is the case, the caregiver should face this reality and consider whether somebody else will function perhaps more appropriately. Even the patient/person will be exposed to an experience of distancing and detachment, which immediately impacts on the atmosphere within the space of encounter. In psychology this process of atmospheric exchange has been called transfer and contra-transfer: the sensitivity of the other for attitude and emotional exchange.

The conviction that one is affirmed in one's ontic stance in life by the cross and resurrection of Christ (the eschatological and theological dimension in healing), should be used as the motivational and intentional factor for the shifting of positions into the direction of the more constructive quadrants. Life can be healed when one discovered that the fruit of the Spirit equips one to change 
one's attitude, to shift one's position, and to develop a different perspective on painful life events.

\section{THE ATMOSPHERIC DYNAMICS OF SPACE AND POSITIONING IN CAREGIVING}

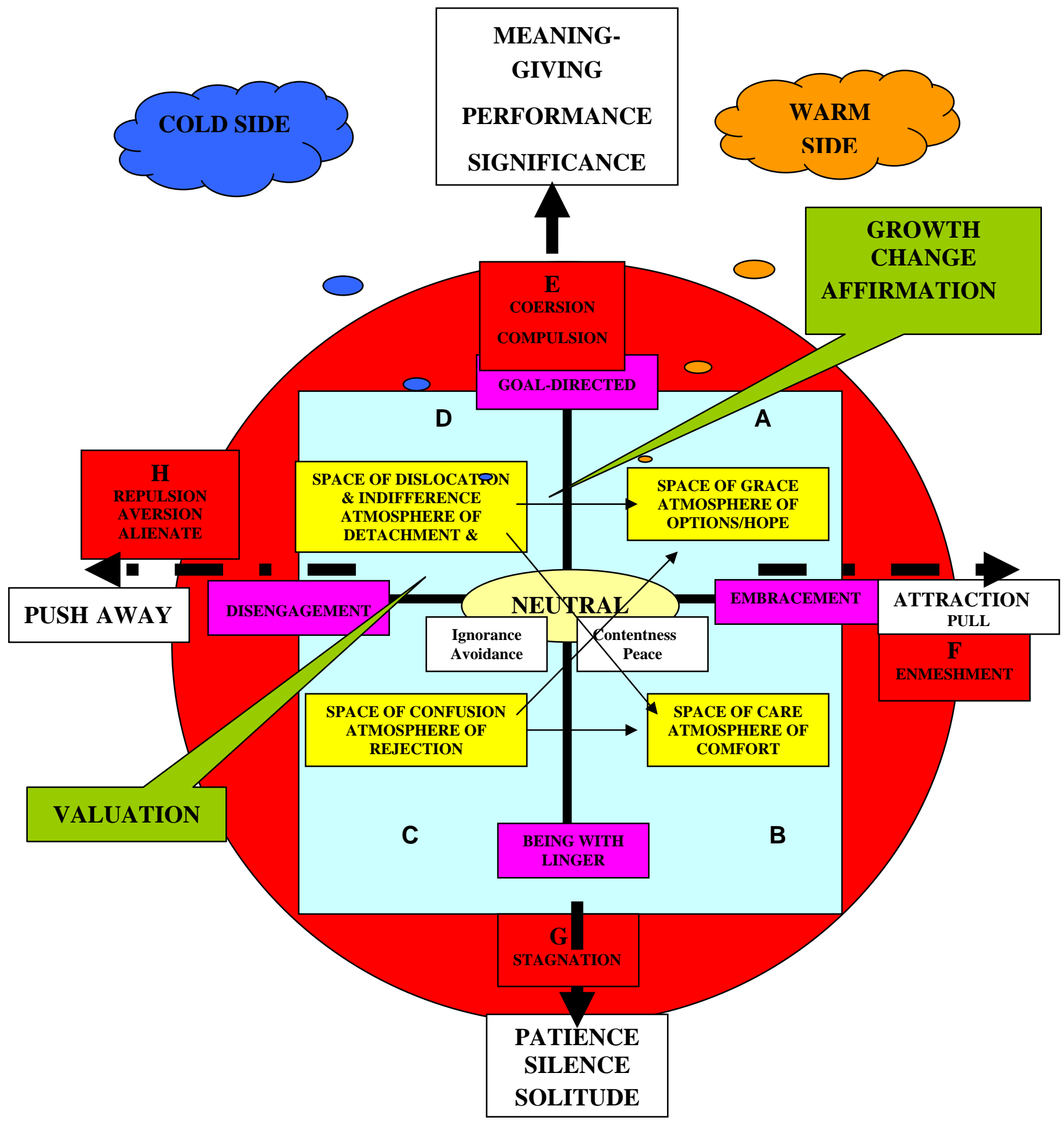




\section{Consulted literature}

Baudrillard, J 1994. Simulacra and Simulation. Michigan: University of Michigan Press.

Castells, M 2004'. The Power of Identity. Volume II. The Information Age: Economy, Society and Culture. Malden: Blackwell Publishing.

Coenen, L 1975. 'Eklegomai', in Brown C (ed.), The New International Dictionary of New Testament Theology, Vol 1. Exeter: Paternoster Press, 536-543.

Collins, G B \& Culbertson T 2003. Mental Illness and Psychiatric Treatment. A Guide for Pastoral Counsellors. New York: The Hayworth Press.

Eiesland, N L 1994. The Disabled God. Toward a Liberatory Theology of Disability. Nashville: Abingdon Press.

Grosz, E 1995. Space, Time, and Perversion. London: Routledge.

Fuehrer, R 1960. Besuch und Seelsorge im Krankenhaus. Göttingen: Vandenhoeck \& Ruprecht.

Haacker, K 1978. Samaritan, in Brown, C (ed.) The New International Dictionary of New Testament Theology, Vol 1. Exeter: Paternoster Press, 449-466.

Hunt, S J 2003. Alternative Religions. A sociological Introduction. Hampshire: Ashgate.

Louw, D J. 2000. Meaning in Suffering. A Theological Reflection on the Cross and the Resurrection for Pastoral Care and Counselling. Frankfurt: Peter Lang.

Long, W M 2000. Health, Healing and God's Kingdom. New Pathways to Christian Health Ministry in Africa. Carlisle: Regnum Books.

Lamb, W W H et al 2001. 'Wholeness, Dignity and the Ageing Self': a Conversation between Philosophy and Theology, in MacKinley, E et al. Aging, Spirituality and Pastoral Care. A Multi-National Perspective. New York: The Haworth Pastoral Press, 75-76.

Moltmann, J 1966 ${ }^{5}$. Theologie der Hoffnung. München: Kaiser.

-, 1972. Der gekreuzigte Gott. München: Kaiser.

Økland, J 2004. 'Men are from Mars and Women from Venus'; on the Relationship between Religion, Gender and Space, in King, U \& Beattie, T (eds.), Gender, Religion and Diversity. Cross-cultural Perspectives. London: Continuum, 152-161.

Pilch, J J 2000. Healing in the New Testament. Insights from Medical and Mediterranean Anthropology. Minneapolis: Fortress Press.

Schmidt, P 1975. Chōreō. In: C Brown (ed.) The New International Dictionary of New Testament Theology, Vol. 1. Exeter: Paternoster Press, 741-742. 
Strümpfer, D J W 1995. The origins of health and strength: from "salutogenesis" to "fortigenesis". South African Journal of Psychology. 25(2), 81-89.

Strümpfer, J W 2006. The Strenghts Perspective: Fortigenesis in Adult Life. Journal for Social Indicators Research, 77(1), 11-36.

Uys, L R \& Mulder M 1984. Verpleegkunde: Menslike wetenskaplike gesondheidsorg. Pretoria: HAUM.

Van Dyk, A. $2005^{3}$. HIV/AIDS Care and Counselling. A Multydisciplinary Approach. Cape Town: Maskew Miller

Wilkinson, J 1998. The Bible and Healing. A Medical and Theological Commentary. Edinburgh: The Handsel Press. 